\title{
Diagnosis Kesulitan Penyelesaian Soal Matematika Pokok Bahasan Pecahan pada Siswa SD Muhammadiyah 2 Kota Sorong
}

\author{
${ }^{1}$ Rahmatullah Bin Arsyad, ${ }^{2}$ Abdul Hakim \\ ${ }^{1}$ Fakultas Keguruan dan Ilmu Pendidikan, Universitas Muhammadiyah Sorong \\ ${ }^{2}$ Fakultas Keguruan dan Ilmu Pendidikan, Universitas Muhammadiyah Sorong \\ Email: rahmatullahbinarsyad@gmail.com,ah2671416@gmail.com
}

\begin{abstract}
Abstrak
Penelitian ini dilakukan dikarenakan banyak siswa yang mengalami kesulitan dalam belajar. Hal ini dilihat dari nilai tugas dan ulangan siswa, semakin tinggi kelasnya maka semakin rendah nilainya. Penelitian ini bertujuan untuk mengetahui (1) Jenis-jenis kesulitan yang dialami oleh siswa dalam menyelesaian soal pokok bahasan pecahan dan cara mengatasinya (2) Penyebab kesulitan penyelesaian soal matematika pada siswa dalam menyelesaian soal pokok bahasan pecahan. Penelitian ini adalah Penelitian Deskriptif yang menjelaskan data dari hasil penelitian. Subyek penelitian ini adalah seluruh siswa kelas V SD Muhammadiyah 2 Kota Sorong tahun ajaran 2015/2016 yang terbagi menjadi dua kelas yaitu kelas VA terdiri dari 31 siswa dan Kelas VB terdiri dari 28 siswa. Penelitian ini untuk mendiagnosis kesulitan penyelesaian soal matematika pokok bahasan pecahan. Langkah mendiagnosis adalah sebagai berikut : (1) Data deskriptif diperoleh melelui tes pecahan, wawancara, angket dan dokumentasi (2) Data kuantitatis dan kualitatif diperoleh melalui angket dan jawaban siswa dalam tes pecahan. Penyebab kesalahan siswa dalam menyelesaikan soal matematika pokok bahasan pecahan adalah kesalahan dalam memahami konsep sebesar $45 \%$, kesalahan dalam menerima informasi sebesar $48 \%$ dan kesalahan dalam menghitung sebesar $46 \%$. Presentase kesalahan tersebut tergolong kurang sehingga kemampuan yang dimiliki siswa rendah.
\end{abstract}

Kata Kunci : Diagnosis, Matematika, Pecahan

\section{PENDAHULUAN}

Pendidikan dasar merupakan suatu jenjang pendidikan yang sangat menentukan terhadap hasil pendidikan. Hal ini disebabkan bahwa pembelajaran di tingkat dasar ini merupakan pondasi yang sangat bermanfaat untuk memasuki jenjang pendidikan yang lebih tinggi. Pembelajaran dilaksanakan pada tahap awal atau dasar harus benar-benar mantap, karena kesulitan belajar yang dialami siswa di tahap awal akan berpengaruh terhadap transfer belajar pada tahap selanjutnya. Sebagaimana kurikulum yang dirancang di dalam proses belajar matematika, yaitu agar siswa mampu melakukan penelusuran pola dan hubungan (Depdiknas, 2006), artinya setiap bahasan dalam matematika saling berkaitan satu sama lain.

Matematika adalah salah satu pengetahuan tertua dan dianggap sebagai induk atau alat dan bahasa dasar banyak ilmu. Matematika terbentuk dari penelitian bilangan dan ruang yang merupakan suatu disiplin ilmu yang berdiri sendiri dan tidak merupakan cabang dari ilmu pengetahuan alam. Matematika pada suatu tingkat rendah terdapat ilmu hitung, ilmu ukur dan 
aljabar (bagian dari matematika dan perluasan dari ilmu hitung, yang banyak digunakan diberbagai bidang disiplin lain, misal fisika, kimia, biologi, teknik, komputer, industri, ekonomi, kedokteran dan pertanian). Menurut Gagne (Fajar, 2010 : 2), dalam belajar matematika ada dua objek yang dapat diperoleh siswa, yaitu objek langsung dan objek tak langsung. Objek langsung terdiri dari fakta, konsep, skill, dan prinsip. Fakta biasanya meliputi istilah (nama), notasi (lambang/simbol), dan lain-lainnya. Sedangkan konsep merupakan ide abstrak yang memungkinkan untuk mengelompokkan objek ke dalam contoh dan non contoh. Skill berkaitan dengan kemampuan siswa dalam memberikan jawaban dan prinsip dapat berupa gabungan konsep dan beberapa fakta. Setelah siswa belajar matematika diharapkan siswa memperoleh keempat hal tersebut. Matematika yang dipelajari di sekolah dasar beragam seperti operasi bilangan bulat, penjumlahan, pengurangan, perkalian, pembagian, pecahan, pemfaktoran, geometri dan lain sebagainya.

Dari hasil observasi peneliti di lapangan nilai untuk mata pelajaran matematika pada siswa SD Muhammadiyah 2 Kota Sorong dikatakan masih rendah, hal ini berdasarkan dari rata-rata tugas harian dan nilai ulangan harian mata pelajaran matematika kebanyakan berada di bawah nilai KKM (Kriteria Ketuntasan Minimal) yaitu 65. Konsep materi pembelajaran yang kurang dikuasai menjadikan hasil belajar siswa pula yang rendah. Ketika diadakan ujian matematika pada siswa di SD Muhammadiyah 2 kota Sorong ternyata menunjukkan bahwa nilai rata-rata mereka tiap semesternya dapat dikatakan senantiasa menurun dan senantiasa berada di bawah kriteria ketuntasan minimal seperti yang dicanangkan sekolah tersebut. Hal ini menunjukkan bahwa konsep pembelajaran belum dikuasai siswa. Dari sini dimungkinkan bahwa siswa tersebut mempunyai kesulitan yang bertambah dalam belajar matematika. Ulangan harian serta ujian akhir semester di SD Muhammadiyah 2 didapatkan temuan bahwa nilai rata-rata untuk matematika dari kelas I menuju ke kelas VI semakin menurun, dan penurunan ini terlihat jelas dari siwa kelas IV ke siswa kelas VI. Hal ini dimungkinkan adanya tingkat kesulitan belajar matematika yang lebih tinggi dibanding kelas-kelas lainnya.

Abdurahman dalam kutipan Kusmanto (2003) menyatakan rendahnya hasil belajar matematika dimungkinkan beberapa kekeliruan umum dilakukan siswa berkesulitan belajar matematika yaitu dalam memahami simbol, nilai tempat, perhitungan, penggunaan proses yang keliru, dan tulisan yang tidak dapat dibaca. Pembelajaran tidak terlepas dari operasi hitung. Baik operasi penjumlahan, pengurangan, perkalian, maupun pembagian. Sama halnya dengan materi operasi pecahan. Semua itu memerlukan operasi hitung. Pecahan merupakan salah satu materi 
penting dalam matematika. Pecahan mencakup konsep-konsep dasar dan merupakan materi prasyarat untuk mempelajari dan memahami jenis bilangan yang lain seperti bilangan riil dan kompleks. Selain itu materi pecahan juga sangat diperlukan siswa untuk mengembangkan kemampuan penalaran aljabar untuk kelas berikutnya. (Yuso dan Malone dalam Noraida Ariyunta, 2012)

Menurut Thorndike dan Hagen yang dikutip oleh Wiwik dalam Sugiharto (2003) diagnosis dapat diartikan sebagai berikut : (i) Upaya atau proses menemukan kelemahan atau penyakit apa yang dialami seseorang dengan melalui pengujian dan studi yang seksama mengenai gejalagejalanya. (ii) Studi yang seksama terhadap fakta sesuatu hal untuk menemukan karakteristik atau kesalahan-kesalahan dan sebagainya yang esensial. (iii) Keputusan yang dicapai setelah dilakukan studi yang seksama atas gejala atau fakta tentang suatu hal. Dari beberapa uraian di atas, diagnosis dapat diartikan suatu uapaya untuk menemukan penyakit atau kelemahan yang dialami seseorang setelah melaui suatu pengujian untuk mendapatkan keputusan atas gejala tentang suatu hal. Dalyono (2009 : 229) menyatakan dalam keadaan dimana siswa tidak dapat belajar sebagaimana mestinya, itulah yang disebut dengan kesulitan belajar. Kesulitan belajar tersebut tidak selalu disebabkan karena faktor intelegensia yang rendah, akan tetapi dapat juga disebabkan oleh faktor-faktor non intelegensia.

Beberapa kesalahan umum yang dilakukan oleh siswa yang bekesulitan dalam belajar matematika menurut Lerner dalam Sugiharto (2003) adalah kekurangan pemahaman tentang simbol, nilai tempat, perhitungan, penggunaan proses yang keliru dan tulisan yang tidak terbaca. Sedangkan kesalahan siswa dalam mengerjakan matematika merupakan kesalahan dasar, kesalahan dalam pemahaman soal, kesalahan dalam pengambilan keputusan dan kesalahan dalam hal perhitungan. Beberapa penelitian sebelumnya menunjukkan kesulitan belajar matematika siswa berkaitan dengan persolan aljabar terkait dengan konsep dan prinsip serta faktor-faktor yang menyebabkan kesulitan belajar siswa berasal dari factor ekstern, yaitu penggunaan alat peraga dari guru belum dapat berperan secara optimal (Hidayatai: 2010), kesalahan keterampilan proses (Mutmainnah: 2013), belum memahami konsep (Untary: 2013, Ariyunita: 2012). Penelitian yang dilakukan sebelumnya hanya sebatas pada mempelajari dan mengetahui jenis-jenis kesulitan yang dihadapi siswa, akan tetapi dalam penelitian yang dilakukan ini diupayakan untuk mendapatkan langkah dalam mengatasi kesulitan yang dialami siswa dalam belajar matematika khususnya dalam menyelesaikan soal matematika dengan cepat dan benar. 
Berdasarkan uraian di atas ternyata ada permasalahan yaitu rendahnya kualitas pemahaman konsep-konsep pada pokok bahasan pecahan terutama pada operasi penyelesaiannya. Berdasarkan dari latar belakang di atas, identifikasi masalah dan pembatasan masalah dapat dikemukaan rumusan masalah sebagai berikut : (1) Apa saja jenis-jenis kesulitan yang dialami oleh siswa kelas V SD Muhammadiyah 2 kota Sorong dalam menyelesaikan persoalan pecahan? (2) Apa saja yang menjadi penyebab kesulitan penyelesaian soal matematika pada siswa kelas V di SD Muhammadiyah 2 kota Sorong?

\section{METODE PENELITIAN}

Penelitian ini adalah penelitian deskriptif yaitu menjelaskan data dari hasil penelitian. Penelitian ini menggunakan pendekatan kualitatif dan kuantitatif. Penelitian ini dilakukan dengan adanya kerjasama antara peneliti dan guru kelas V SD Muhammadiyah 2 Kota Sorong.

Subyek penelitian ini adalah siswa-siswi kelas V SD Muhammadiyah 2 Kota Sorong tahun ajaran 2015/2016 yang mengalami kesulitan dalam menyelesaikan soal pecahan. Pada SD Muhammadiyah 2 Kota Sorong untuk kelas V terdapat 2 kelas yaitu kelas V A terdiri dari 31 siswa dan Kelas V B terdiri dari 28, dengan kemampuan setiap kelas heterogen.

Penelitian diadakan di kelas V SD Muhammadiyah 2 Kota Sorong tahun ajaran 2015/2016 pada bulan Agustus - Oktober 2015.

Instrumen penelitian yang akan digunakan dalam penelitian ini adalah : (a) Tes pecahan. Tes pecahan merupakan tes yang dirancang untuk keperluan mendiagnosis kesalahan-kesalahan yang dilakukan siswa dalam menyelesaikan persoalan pecahan. Berdasarkan hasil tes tersebut dapat diidentifikasi kesulitan siswa berupa kesalahan-kesalan siswa dalam menjawab soal yang berkaitan dengan konsep pecahan. Kesalahan-kesalahan inilah yang menjadi kesulitan siswa. (b) Angket, digunakan untuk mengetahui faktor-faktor penyebab kesulitan siswa dalam menjawab soal pecahan. (c) Wawancara, dirancang untuk mempermudah peneliti dalam menggali informasi tentang hasil pekerjaan siswa pada tes pecahan yang diberikan. (d) Dokumentasi dengan mencatat atau mengabadikan kegiatan berupa foto dan arsip-arsip nilai serta pekerjaan siswa. 


\section{HASIL DAN PEMBAHASAN}

Penelitian yang dilakukan ini menggunakan 4 langkah dalam desain kerjanya yaitu (1) tahap persiapan pelaksanaan tes, (2) tahap pelaksanaan tes, (3) tahap diagnosa dan wawancara dan (4) tahap kesimpulan. Tes diberikan setelah semua materi selesai diberikan, berdasarkan hasil jawaban siswa dalam mengerjakan soal-soal pada materi pecahan tersebut terdapat beberapa kesalahan yang dilakukan oleh beberapa siswa. Dari diagnosa kesalahan jawaban siswa dalam menyelesaikan soal pecahan diperoleh data yang digunakan untuk menghitung presentase tiap kesalahan.

\section{Diagnosa Penyebab Kesalahan}

Dari beberapa jawaban yang didapatkan ternyata beberapa siswa tidak mengerjakan seperti yang diharapkan, hal ini dimungkinkan bahwa siswa tersebut memang sepenuhnya tidak mengerti dan memahami konsep. Namun ada juga yang dimungkinkan karena konsep prasyarat yang dimiliki kurang. Kemungkinan kesulitan dalam menyelesaikan soal pecahan yang diduga menjadi penyebab kesalahan adalah :

1. Kesalahan yang dialami siswa dalam mengerjakan soal pecahan adalah sebagai berikut :

a. Penjumlahan dan pengurangan pada bilangan pecahan

1) Menjumlah atau mengurangi pembilang dan penyebut dengan penyebut.

2) Salah dalam mengubah bilangan pecahan campuran menjadi pecahan biasa dan salah mengubah bilangan pecahan biasa menjadi pecahan campuran.

3) Penyebut telah disamakan akan tetapi pembilang pada soal pecahan belum disesuaikan.

4) Salah dalam menentukan KPK (Kelipatan Persekutuan Terkecil) untuk menyamakan penyebutnya.

5) Salah dalam menyederhanakan hasil akhir.

6) Tidak teliti dalam menjumlah atau mengurangi.

b. Perkalian bilangan pecahan

1) Mengalikan bilangan bulat dengan bilat bulat kemudian mengalikan bagian pecahan dan pecahan.

2) Salah dalam mengubah bilangan pecahan biasa menjadi pecahan campuran.

3) Melakukan hal yang sama seperti operasi pecahan penjumlahan dan pengurangn yaitu menyamakan penyebutnya terlebih dahulu baru kemudian mengalikannya.

4) Salah menhyerdehanakan hasil akhir,

5) Tidak teliti dalam menentukan hasil akhir pada operasi pecahan perkalian. 
c. Pembagian bilangan pecahan

1) Salah dalam menentukan pecahan yang dibalik, bagian yang dibagi dibalik (yang dibalik seharusnya pembagi).

2) Pada pembagian pecahan biasa, langsung membagi pembilang dengan pembilang dan penyebut dengan penyebut atau penyebutnya tetap.

3) Pada pembagian pecahan campuran, langsung membagi bagian bilangan bulat dengan bilangan bulat dan pecahan dengan pecahan (pembilang dengan pembilang dan penyebut dengan penyebut atau penyebutnya dibuat tetap)

4) Salah dalam mengubah pecahan campuran menjadi pecahan biasa terlebih.

5) Tidak teliti dalam menentukan hasil akhir.

Tabel 4.1 Perhitungan Presentase Analisa Kesalahan Siswa

\begin{tabular}{lcccccccccccc}
\hline \multirow{2}{*}{ Jenis Kesalahan } & Jenis & \multicolumn{10}{c}{ Nomor Item } & \multirow{2}{*}{ Jumlah } \\
\cline { 2 - 12 } & Item & 1 & 2 & 3 & 4 & 5 & 6 & 7 & 8 & 9 & 10 & \\
\hline Kesalahan & $\sum B$ & 40 & 36 & 38 & 34 & 36 & 28 & 33 & 26 & 24 & 32 & 327 \\
memahami konsep & $\sum S$ & 19 & 23 & 21 & 25 & 23 & 31 & 26 & 33 & 35 & 27 & 263 \\
Kesalahan menerima & $\sum B$ & 42 & 32 & 34 & 36 & 30 & 28 & 27 & 27 & 28 & 24 & 308 \\
informasi & $\sum S$ & 17 & 27 & 25 & 23 & 29 & 31 & 32 & 32 & 31 & 35 & 282 \\
Kesalahan dalam & $\sum B$ & 45 & 40 & 37 & 30 & 34 & 25 & 26 & 20 & 32 & 30 & 319 \\
menghitung & $\sum S$ & 14 & 19 & 22 & 29 & 25 & 34 & 33 & 39 & 27 & 29 & 271 \\
\hline
\end{tabular}

Berdasarkan hasil pekerjaan siswa yang ada, maka berikut ini diperoleh beberapa kessalaha-kesalahan yang dilakukan siswa untuk mengetahui faktor-faktor yang menyebabkan kesalahan.

1. Kesalahan dalam memahami konsep

a. Siswa salah dalam mengubah pecahan campuran menjadi pecahan biasa

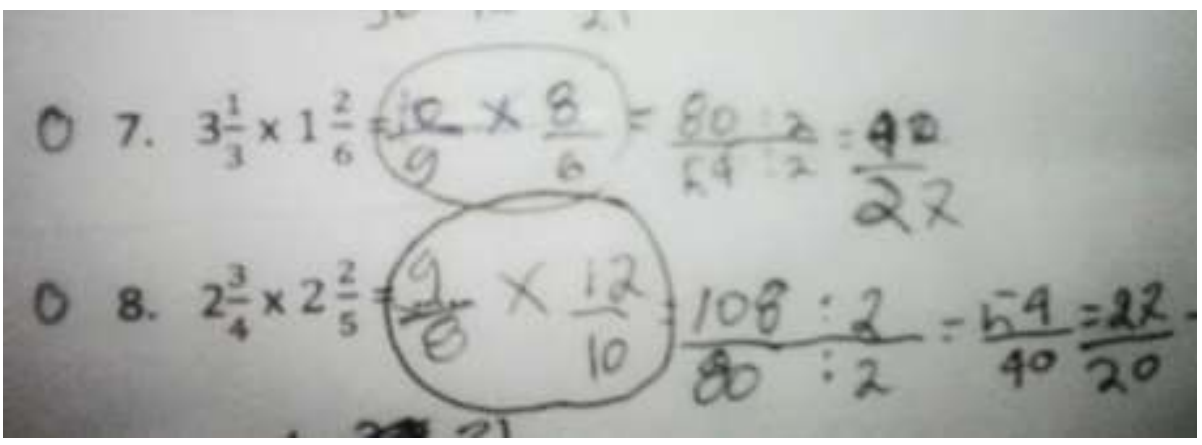


Jawaban siswa di atas, siswa diminta untuk mencari penyelesaian dari soal pecahan perkalia, dalam soal tersebut siswa salah dalam mengubah pecahan campuran menjadi pecahan biasa. Dari hasil wawancara siswa, diperoleh bahwa beberapa dari mereka lupa serta masih bingung dengan cara merubah pecahan campuran menjadi pecahan biasa.

b. Siswa salah dalam menyelesaikan soal pecahan pembagian

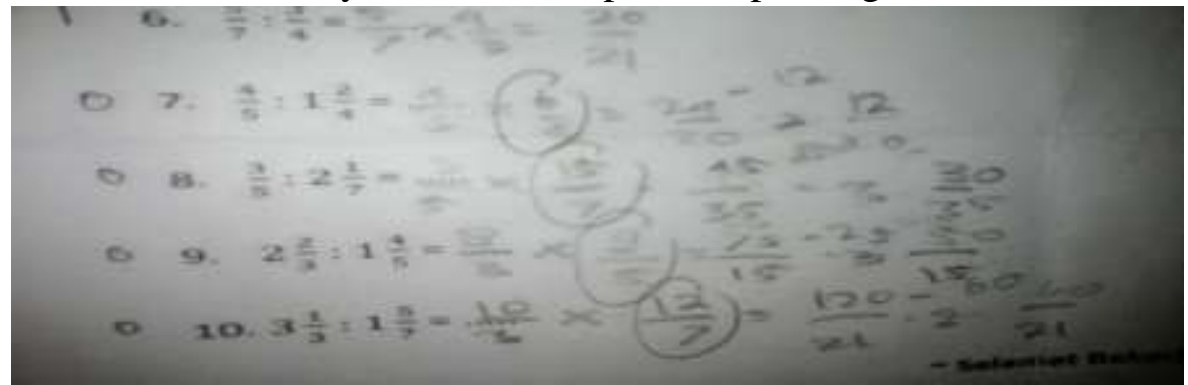

Dalam jawaban soal tersebut siswa menyelesaikan soal pecahan pembagian sama dengan pecahan perkalian yaitu pembagi tidak dibalik. Kesalahan tersebut disebabkan karena siswa beranggapan bahwa cara menyelesaikan soal pecahan pembagian dan perkalian menggunakan cara yang sama.

Berdasarkan hasil diagnosa jawaban tes dan wawancara, diperoleh bahwa siswa melakukan kesalahan karena bingung dengan cara merubah pecahan campuran menjadi pecahan biasa, serta beranggapan bahwa cara menyelesaikan soal pecahan pembagian sama dan pecahan perkalian menggunakan cara yang sama.

2. Kesalahan dalam menerima informasi

a. Kesalahan dalam menulis tanda operasi hitung

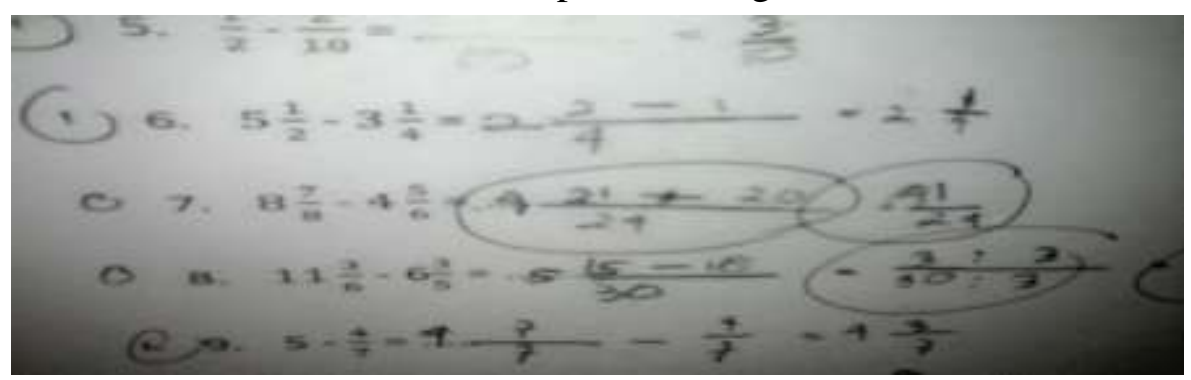

Pada soal nomor 7 siswa salah dalam menggunakan tanda operasi hitung. Hal ini tidak sesuai dengan perintah dari soal. Dari hasil wawancara siswa tidak teliti dan terlalu terburu-buru dalam menyelesaikan soal tanpa melakukan pengecekan kembali. 
b. Kesalahan tidak sesuai perintah soal

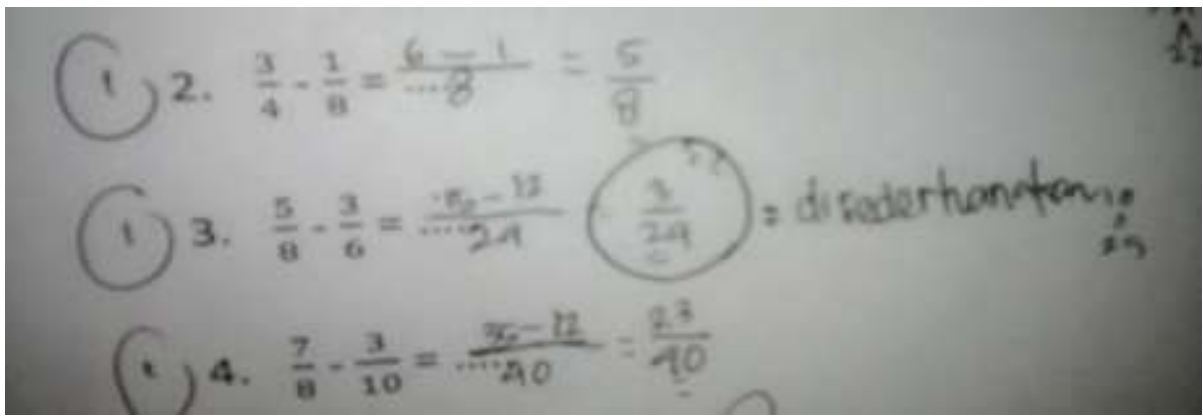

Pada soal nomor 3 di atas, jawaban siswa sudah tepat hanya tidak sesuai dengan apa yang diperintahkan yaitu setiap jawaban apabila masih dapat disederhanakan sekecil mungkin maka sederhanakanlah. Dari hasil wawancara siswa hal tersebut disebabkan karena siswa kurang memperhatikan perintah soal.

Berdasarkan hasil diagnosa jawaba soal tes dan wawancara siswa, diperoleh bahwa siswa melakukan kesalahan dalam menerima informasi, tidak memperhatikan perintah soal, terburu-buru dalam mengerjakan soal serta tidak teliti.

3. Kesalahan dalam menghitung

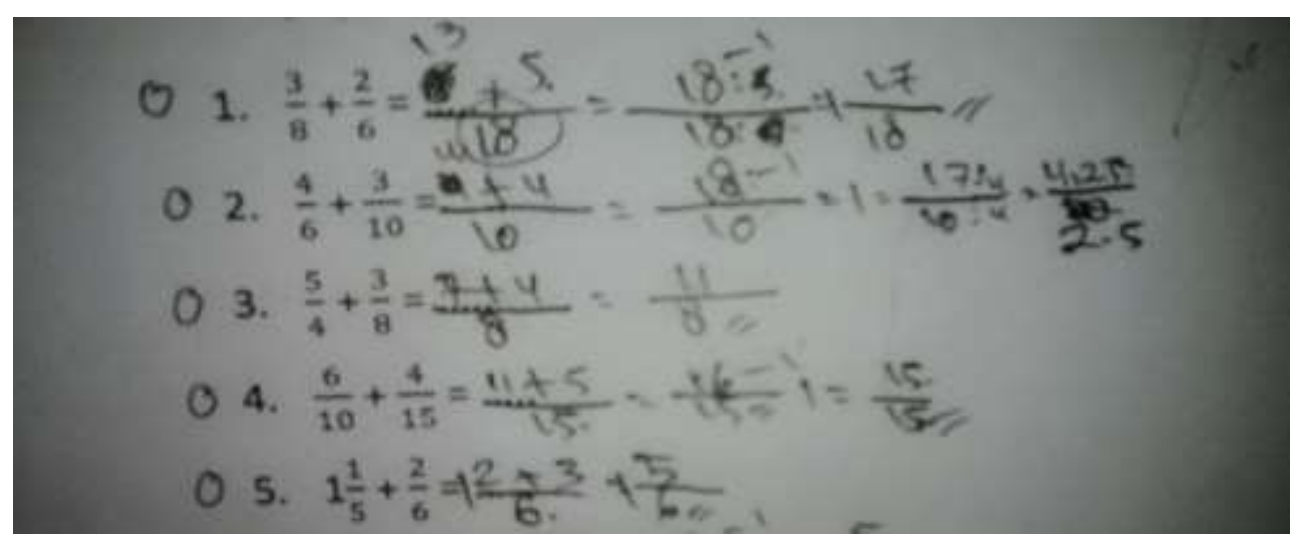

Dari jawaban siswa di atas, siswa melakukan kesalahan dalam soal pecahan penjumlahan, hal ini dikarenakan siswa tidak paham konsep soal terutama dalam menentukan KPK dari kedua penyebut. Akibatnya secara keseluruhan soal yang dikerjakan salah dalam perhitungan. 
Tabel 4.2 Kualifikasi Presentasi Nilai Keaktifan Siswa

\begin{tabular}{clcc}
\hline No. & \multicolumn{1}{c}{ Jenis Kesalahan } & Nilai Keaktifan & $\begin{array}{c}\text { Taraf } \\
\text { Keberhasilan }\end{array}$ \\
\hline 1 & $\begin{array}{l}\text { Kesalahan memahami } \\
\text { konsep }\end{array}$ & $45 \%$ & D (Kurang) \\
2 & $\begin{array}{l}\text { Kesalahan menerima } \\
\text { informasi }\end{array}$ & $48 \%$ & D (Kurang) \\
3 & Kesalahan dalam menghitung & $46 \%$ & D (Kurang) \\
\hline
\end{tabular}

Berdasarkan perhitungan dari analisa kesalahan siswa, jika dibandingkan dengan kriteria kualifikasi presentase nilai keaktifan siswa maka taraf keberhasilan kesalahan memahami konsep memcapai taraf kurang, kesalahan menerima informasi mencapai taraf kurang dan kesalahan dalam menghitung mencapai taraf kurang.

Tabel 4.3 Presentase Angket Diagnosis Kesulitan Belajar Siswa

\begin{tabular}{llcccc}
\hline \multirow{2}{*}{$\begin{array}{l}\text { N } \\
\mathrm{O}\end{array}$} & \multicolumn{4}{c}{ Tanggapan } \\
\cline { 2 - 6 } & $\mathrm{SS}$ & $\mathrm{S}$ & $\mathrm{TS}$ & $\mathrm{STS}$ \\
\hline 1 & Materi pecahan adalah materi yang mudah bagi saya. & 4 & 3 & 2 \\
\hline 2 & $\begin{array}{l}\text { Saya merasa bisa memahami materi pecahan lebih cepat } \\
\text { dari teman-teman saya. }\end{array}$ & 0 & 10 & 2 & 47 \\
\hline 3 & $\begin{array}{l}\text { Ketika diberikan soal materi pecahan, saya selalu } \\
\text { mengerjakannya dengan baik. }\end{array}$ & 20 & 6 & 11 & 22 \\
\hline 4 & $\begin{array}{l}\text { Saya paham langkah-langkah dalam menyelesaikan soal } \\
\text { pecahan penjumlahan, pengurangan, perkalian dan } \\
\text { pembagian. }\end{array}$ & 15 & 8 & 6 & 30 \\
\hline 5 & $\begin{array}{l}\text { Saya senang dengan cara mengajar guru mengenai materi } \\
\text { pecahan karena sangat mudah dipahami. }\end{array}$ & 36 & 12 & 4 & 7 \\
\hline \multicolumn{1}{c}{ Jumlah Skor Dicapai } & 89 & 48 & 28 & 130 \\
\hline
\end{tabular}

Hasil perhitungan presentase dari masing-masing faktor pada angket diagnosis kesulitan siswa di atas dikualifikasikan pada tabel berikut :

Tabel 4.4 Kualifikasi presentase faktor pada angket diagnosis

\begin{tabular}{clcc}
\hline No & Pernyataan & $\begin{array}{c}\text { Presentase } \\
\text { Penyebab }\end{array}$ & $\begin{array}{c}\text { Kualifikasi } \\
\text { Penyebab }\end{array}$ \\
\hline 1 & Sangat Setuju & $30 \%$ & Kuat \\
2 & Setuju & $16 \%$ & Sangat Kuat \\
3 & Tidak Setuju & $9 \%$ & Sangat Kuat \\
4 & Sangat Tidak Setuju & $44 \%$ & Cukup \\
\hline
\end{tabular}




\section{SIMPULAN}

Berdasarkan hasil penelitian dan pembahasan, maka dapat disimpulkan :

1. Kesulitan yang dialami siswa dalam penyelesaian soal materi pecahan

a. Kesalahan dalam memahami konsep yaitu salah satunya kesulitan siswa dalam mengubah pecahan campuran menjadi pecahan biasa dan kesalahan siswa dalam menyelesaikan soal pecahan pembagian sama dengan pecahan perkalian yaitu pembagi tidak dibalik.

b. Kesalahan dalam menerima informasi yaitu kesalahan dalam menggunakan operasi hitung yang tidak sesuai dengan perintah soal serta penyelesaian akhir yang tidak sesuai perintah.

c. Kesalahan dalam menghitung.

2. Penyebab terjadinya kesulitan siswa dalam penyelesaian soal materi pecahan

a. Kesalahan dalam memahami konsep

Penyebab kesalahan dalam memahami konsep yaitu siswa lupa serta masih bingung dengan cara merubah pecahan campuran menjadi pecahan biasa dan siswa beranggapan bahwa cara menyelesaikan soal pecahan pembagian sama dan pecahan perkalian menggunakan cara yang sama.

b. Kesalahan dalam menerima informasi

Penyebab kesalahan dalam menerima informasi yaitu siswa siswa tidak teliti dan terlalu terburu-buru dalam menyelesaikan soal tanpa melakukan pengecekan kembali sehingga apa yang dikerjakan siswa tidak sesuai dengan perintah soal atau informasi yang diberikan.

c. Kesalahan dalam menghitung

Penyebab kesalahan dalam menghitung yaitu siswa kurang teliti dan terburu-buru dalam menyelesaikan soal.

3. Presentase kesulitan siswa sehingga salah dalam menyelesaikan soal materi pecahan

a. Kesalahan yang dilakukan siswa dalam memahami konsep sebesar $45 \%$. Presentase kesalahan tersebut tergolong kurang sehingga kemampuan yang dimiliki siswa rendah.

b. Kesalahan yang dilakukan siswa dalam menerima informasi sebesar $48 \%$. Presentase kesalahan tersebut tergolong kurang sehingga kemampuan yang dimiliki siswa rendah. 
c. Kesalahan yang dilakukan siswa dalam menghitung sebesar $46 \%$. Presentase kesalahan tersebut tergolong kurang sehingga kemampuan yang dimiliki siswa rendah.

d. Kesalahan-kesalahan tersebut dapat dipergunakan oleh guru di sekolah sebagai bahan pertimbangan dalam merancang kegiatan pembelajaran agar lebih baik. Dengan mengetahui kesulitan siswa dalam menyelesaikan soal, guru dapat mengantisipasi agar tidak terulang lagi, memberi pemahaman pada siswa serta meningkatkan kemampuan dalam menyelesaikan soal-soal yang lebih beragam lagi. Dalam belajar hendaknya siswa tidak hanya menghafal rumus matematika tetapi juga berusaha dalam memahami konsep yang diberikan, selain itu siswa harus lebih banyak latihan dalam mengerjakan soal dan lebih teliti dalam membaca perintah soal.

\section{DAFTAR PUSTAKA}

Arikunto, Suharsimi. 2009. Dasar-dasar Evaluasi Pendidikan. Jakarta : Bumi Aksara.

Ariyunita, Noraida. Analisis Kesalahan Dalam Penyelesaian Soal Operasi Bilangan Pecahan. Skripsi. Fakultas keguruan dan Ilmu Pendidikan, Universitas Muhammadiyah Surakarta : Surakarta (Tidak Dipublikasikan).

Bin Arsyad, Rahmatullah. Meningkatkan Hasil Belajar Matematika Dengan Menggunakan Model Cooperative Learning Dan Tekhnik Napier Pada Siswa Kelas Iv $^{\text {b }}$ Sd Muhammadiyah 2 Kota Sorong. Skripsi. Fakultas Keguruan dan Ilmu Pendidikan, Universitas Muhammadiyah Sorong : Sorong (Tidak Dipublikasikan)

Dahar, R. W. 2006. Teori-teori Belajar \& Pembelajaran. Jakarta: Erlangga.

Hidayati, Fajar. Kajian Kesulitan Belajar Siswa Kelas VII SMP Negeri 16 Yogyakarta Dalam Mempelajari Aljabar. Skripsi. Fakultas Matematika dan Ilmu Pengetahuan Alam UNY : Yogyakarta (Tidak Dipublikasikan)

Idel, Anton, Hariyono, Rudy. 2005. Pintar Matematika SMA. Jawa Timur : Gitamedia Press.

Mulyono, Abdurrahman. 2010. Pendidikan Bagi Anak Berkesulitan Belajar. Jakarta: PT Rineke Cipta.

Mutmainnah. 2013. Analisis Kesalahan Siswa Dalam Menyelesaikan Soal Materi Bilangan Berpangkat SMK Dipinegoro Salatiga. Skripsi. Fakultas Keguruan dan Ilmu Pendidikan UKSW : Salatiga (Tidak Dipublikasikan).

Suryaningrum, Rina. Identifikasi Kesalahan Siswa Kelas 3 SLTP dalam Menyelesaikan Soal-soal Pokok Bahasan Persamaan dan Upaya Mengatasinya. (Tidak Dipublikasikan)

Sutama. 2011. Metode Penelitian Pendidikan. Surakarta : Fairus Media 
Untari, Erny. Diagnosis Kesulitan Belajar Pokok Bahasan Pecahan Pada Siswa Kelas V Sekolah Dasar. Tesis. STKIP PGRI : Ngawi (Tidak Dipublikasikan)

Tim Bina Guru. (2006). Terampil berhitung Matematika untuk SD kelas V.Jakarta: Erlangga

Pusat Bahasa Departemen Pendidikan Nasional. Kamus Besar Bahasa Indonesia. Edisi Ketiga. Jakarta : Balai Pustaka

Zain, Aswan, Bahri Syaiful. 2006. Strategi Belajar Mengajar. Jakarta : Rineka Cipta 